\title{
Anaerobic Bioreactor Technology in Brief
}

\author{
by Gede H. Cahyana \\ Lecturer, Kebangsaan University, Rep. of Indonesia
}

In brief, I would like to distribute a topic in anaerobic wastewater treatment. As one of the fundamental system on treatment technology, this kind of bioreactor is offering us an excellent chance to get the best result. Of course, there will be difference on the result of each other. On this research activities, the source of microorganism was rumen which contain a very rich of anaerobic bacteria and obtained from slaughterhouse at Ciroyom, Bandung. Before adaptation or acclimatisation on the reactor, the seeding have been done in the tank for a few of weeks with introduced of glucose and nutrient so trace metals to support their growth.

As we know, effluent from industries, especially food industries all tend to be heavily polluted and contain high concentration of organic matter. Such materials from sugarcane waste like mollasses are generally neither toxic nor even harmful, but they can rapidly exert a substantial oxygen demand when the effluent of the factory is discharged to a watercourse viz. lakes or rivers. As we have known that organic substances in wastewater contain some elements such as CHONSP and usually called as COD (Chemical Oxygen Demand) or BOD (Biochemical Oxygen Demand) and represent the strength of waste so used as indicators for water pollution control.

Biological treatment is one of the famous technology to decrease the pollutant of organic content. Treating municipal or industrial wastewater, one can apply bioreactor which are divided into two general groups depend on their medium of growth viz. suspended growth reactor and attached growth reactor. We also can separate the reactor as aerob and anaerobic reactor due to presence of oxygen. Anaerobic reactor is a bacterial decomposition by which the organic matter is broken down in the absence of dissolved oxygen to produce a mixture of $\mathrm{CO} 2$ and $\mathrm{CH} 4$ gases. The formation of $\mathrm{CH} 4$ gas is the key to the whole process because it is the method by which the COD of the waste is reduced and also 
because the $\mathrm{CH} 4$ content provides a commercial value as fuel for cooking or lighting (electricity).

\section{Historical Aspect}

As the oldest method to treat wastewater, anaerobic technology has some merit than aerob treatment. The first installation used to treat settled wastewater solid was known as Mouras automatic scaverager which developed by Louis $\mathrm{H}$. Mouras, a French engineer in about 1860. So Donald Cameron was the first person recognizing that a combustible gas containing $\mathrm{CH} 4$ was produced when wastewater solid was liquified. This gas so called as "marsh or swamp gas" because burning on the surface of swamps.

At the beginning of this century, the treatment target changed from solids digestion systems to modern municipal wastewater treatment systems generally for combined industrial and domestic wastewater. Simple anaerobic treatment process such as various type of septic tanks were not suitable to treat large quantities of municipal wastewater. Therefore, in 1893 aerobic treatment were built viz. Trickling Filter and in 1914 the Activated Sludge process. Nowadays, these have been developed very widely with any variations in method of technology.

Just like aerobic treatment, as notice before, there are two kinds of common processes for anaerobic treatment i.e suspended growth and attached growth systems. The most common anaerobic attached growth treatment processes are anaerobic filter and fluidized or expanded bed processes and for suspended growth system the most common process is the UASB (Upflow Anaerobic Sludge Blanket) system used for the treatment of domestic wastewater.

\section{Anaerobic Filter}

This type of anaerobic treatment consists of a reactor vessel filled with some proper type of solid media. The wastewater flows upward through the packedbed, containing media on which anaerobic bacteria grow and are retained. Because the bacteria are retained and not washed out with the effluent, mean cell residence times can be obtained up to 100 days. High value of this can be 
achieved at short hydraulic retention times, consequently the anaerobic filter can be used in principle for the treatment of low strength wastewater at ambient temperature.

\section{Fluidized bed and expanded bed reactor}

In both of the reactor, the wastewater is pumped upward through a bed consisting of an approprite medium (sand, coal, bamboo) on which a biological growth has developed. Effluent can be recycled to dilute the incoming wastewater and to provide an adequate flow to maintain the bed in a fluidized or expanded state.

\section{$\underline{\text { UASB Reactor }}$}

The wastewater is introduced at the bottom of the reactor, which first developed by Lettinga in 1972 at Netherland and it then flows upward through a blanket of active anaerobic sludge. Treatment occurs as a result of a proper contact of wastewater with the active sludge. The UASB presently process is the most widely used high rate anaerobic sewage treatment system.

\section{Hybrid Anaerobic Reactor}

This is a new hybrid reactor which combined a filter in the upper of the reactor and suspended growth in the bottom. The height and volume of each part is variable depend on the researchers and may be has different efficiency. From a few of researchs that has been done, we can take a general conclusion that this reactor has a better performance than the others.

\section{Principle of the Process}

Generally, the anaerobic digestion can be divided into three step process accomplished by very large consortia of microorganisms and are distinguished (Wang K, 1994):

a. Hydrolysis, the first step in degradation of organic matter involves reaction of extracellular enzymatic. Many microorganisms produce extracellular enzymes, suited for transformation or hydrolysis of higher molecular mass compounds such as lipid, proteins an carbohydrates into small molecules suitable for use as source of energy and cell carbon. 
b. Acidogenesis is the second step, involves the bacterial conversion of the compounds resulting from the first step (hydrolysis) into intermediate compound such as volatile fatty acids, alcohol, hydrogen, CO2 and other low molecular weight compounds. The acid formers have an optimal $\mathrm{pH}$ between 5-6 although the normal $\mathrm{pH}$ near 7 in which still favorable compared to methanogens (methane formers) for final conversion of organics.

c. The third step is the sequense of aceto- and methanogenesis involves bacterial conversion of the intermediate compounds into methane gas and CO2. CH4 is produced mainly via acetic acid + hydrogen and CO2. Methanogenesis proceeds relatively slowly and generally is the rate limiting in anaerobic degradation. Bacteria that utilize acetate called acetoclastic (acetophilic) bacteria with the overall reaction is $\mathrm{CH} 3 \mathrm{COOH} \rightarrow \mathrm{CH} 4+\mathrm{CO} 2$.

In field of sanitation technology especially in domestic wastewater treatment and solid waste management and disposal, anaerobic bioreactor has been given a chance to clean our environment and also biogas energy which composed of methane ( $\mathrm{CH} 4)$. Of course, it is not easy to have a good treatment process in accordance to environmental condition like $\mathrm{pH}$, temperature, toxic materials, and fluctuations of hydraulic and organic loading all day - night long. However, we have a lot of success stories in this field of waste water treatment, i.e. in the strong organic pollutants. Finally, choose one of them in our researches and try to modify the kind of hybrid and get its secret of success. *

\section{References}

1. Droste, Ronald. L (1997). Theory and Practice of Water and Wastewater Treatment. John Wiley \& Sons, USA

2. Lettinga, G, Hulshof Pol (1991). "Application of Modern High Rate Anaerobic Treatment Processes for Wastewater Treatment." New Development in Industrial Wastewater. Series E, Vol. 191, Ed. Turkman, A., O. Uslu. Kluwer Academic Publishers.

3. Ozturk I., et al. (1993). "Hybrid Upflow Anaerobic Sludge Blanket Reactor (HUASBR) Treatment of Dairy Effluents." Wat. Sci. Tech., Vol. 28, p. 77-85.

4. Speece R.E. (1996). Anaerobic Biotechnology for Industrial Wastewater. Archae Press, Vanderbilt University, England.

5. Wang K. (1994). Integrated Anaerobic-Aerobic Treatment of Sewage. Ph.D Thesis, Wageningen Agricultural University, The Netherlands. 